\title{
単脂環アルコールで表面処理したシリカゲルの 加熱による表面性状の変化*
}

$\begin{array}{lllllll}\text { 宇 津 木 } & \text { 弘** } & \text { 遠 } & \text { 藤 } & \text { 敦*** 鈴 } & \text { 木 } & \text { 昇*** } \\ \text { 花 岡 信 } & \text { 子***菅 } & \text { 野 } & \text { 彰*** } & \text { 曽 場 } & \text { 隆*** }\end{array}$

\section{Studies on Change of Surface Nature of Silica Gel after Pyrolysis of Surface-Treated Silica Gels with Alicyclic Alcohols}

by

\author{
Hiroshi Utsugi, Atsushi Endo, Noboru Suzuki, Nobuko Hanaoka, \\ Akira KANNO, and Takashi SoBA \\ (Faculty of Engineering, Utsunomiya University, Utsunomiya)
}

\begin{abstract}
The pore size distribution and pore structure of the original silica gel used for the present surface-treatment experiments were found to be invariant through the determination of argon adsorption isotherm at $77 \mathrm{~K}$ and the surface area, as long as it was activated at lower temperatures than $450^{\circ} \mathrm{C}$. The silica gel was treated with alicyclic alcohols, e. g., cyclopentanol, cyclohexanol, cycloheptanol, cyclohexane methanol and cyclohexane ethanol in an autoclave. The adsorbed amount of argon at $77 \mathrm{~K}$ on these surface-treated silica gels showed an appreciable decrease in the whole range of relative pressure in comparison with that of the original silica gel and the surface area of these silica gels also decreased. The surface groups of these surface-treated silica gels except the ones treated with cyclohexane methanol or cyclohexane ethanol were driven off from the substrate almost perfectly by pyrolysis of these silica gels at $450^{\circ} \mathrm{C}$. The argon adsorption isotherm at $77 \mathrm{~K}$ and the surface area of these silica gels after pyrolysis at $450^{\circ} \mathrm{C}$ showed a fairly good agreement with those of the original silica gel.
\end{abstract}

キー・ワード : 表面処理, シリカゲル，熱分解

(Received Feb. 16, 1981)

\section{1 緒言}

アルコールでシリカゲルを処理すると, 表面水酸基 はアルコールと脱水縮合し, 使用したアルコールのア ルコキシ基の性質あるいは置換の程度に応じてその表 面性状をかえるようになる。るたこのように処理され たシリカゲルのアルゴン吸着等温線あるいは表面積は， 未処理シリカゲルと比較していずれも減少している. これらの減少は当然のことながらアルコキシ基がその 表面に存在している影響であると考兄られる.この処 理シリカゲルを真空中で加熱して付着基であるアルコ キシ基を離脱させてやると, 吸着等温線, 表面積等の 表面性状が変化することが予想される，本報ではアル コールとして，シクロペンタノール，シクロヘキサノ ール, シクロヘプタノール, シクロヘキシルメタノー

* 原稿受理 昭和56年 2 月 16 日

** 正 会 員 宇都宮大学工学部 宇都宮市石井町

*** 宇都宮大学工学部 宇都宮市石井町
ル, シクロヘキシルエタノールの 5 種類の単脂環アル コールを用いて，加熱による表面性状の変化の検討を 行ったので報告する。

\section{2 実}

\section{験}

シリカゲルの表面处理はオートクレーブ法で行った すなわち市販ガスクロマト用シリカゲル SK4 和よび SK6 を，前に述べたアルコールのへキサン溶液に浸 し，これをオートクレーブ中にてへキサンの臨界点付 近 $\left(240^{\circ} \mathrm{C}, 30 \mathrm{~atm}\right)$ で反応させ，反応後蒸気成分を受 容器に凝縮させた後，シリカゲルを分離する方法であ る.このようにして処理されたシリカゲルは $\mathrm{KBr}$ 錠 剂法により，Perkin Elmer（337型）赤外線分光光度 計で吸収スペクトルを測定して，その処理の程度を確 認した

吸着等温線は吸着質としてアルゴンを用い，その重 量を石英スプリングにより，平衡圧は水銀柱差圧力計 で測定する静置重量法により求めた。 
また，置換基の分解温度等の確認のために，処理シ リカダルの熱分解を行っているが，これは Fig.1 に 示すよらに $2 \mathrm{~mm}$ 石英管につめた試料を $\mathrm{He}$ 気流中 にてほぼ一定な昇温速度 $\left(3^{\circ} \mathrm{C} / \mathrm{min}\right)$ で $800^{\circ} \mathrm{C}$ をで電 気炉で加熱し，発生する蒸気成分を四重極質量分析計 （日電バリアン社製 TE-150）に導入し分析した.

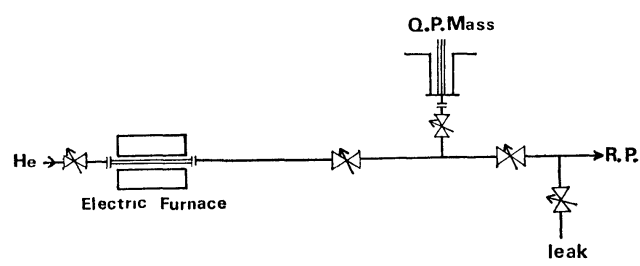

Fig. 1. Schematic diagram of apparatus used for pyrolysis of silica gels treated with alcohols.

\section{3 結果ならびに考察}

\section{$3 \cdot 1$ 未処理シリカゲルの等温線と表面積}

$\mathbf{3} \cdot \mathbf{1} \cdot \mathbf{1}$ 吸着等温線 未処理シリカゲル SK4 を

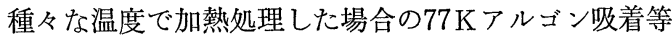
温線を Fig. 2 に示した. 130，250，350 および450 で加熱処理したシリカゲルの吸着等温線はほぽ一致し ている. したがってこれらの温度での加熱処理はシリ カゲルの毛管分布に変化を与えていないと考えられる. しかるに $500^{\circ} \mathrm{C}$ 以上の温度で加熱したシリカゲルでは, その等温線は全比圧範囲で吸着量は減少して括り，し かも加熱温度の上昇するにつれ，その吸着量の減少の

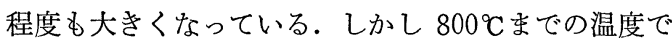
の加熱処理シリカゲルでは単分子吸着量を差し引いた 吸着量は130〜 $450^{\circ} \mathrm{C} て ゙$ 加熱処理したとれにほぼ一致す

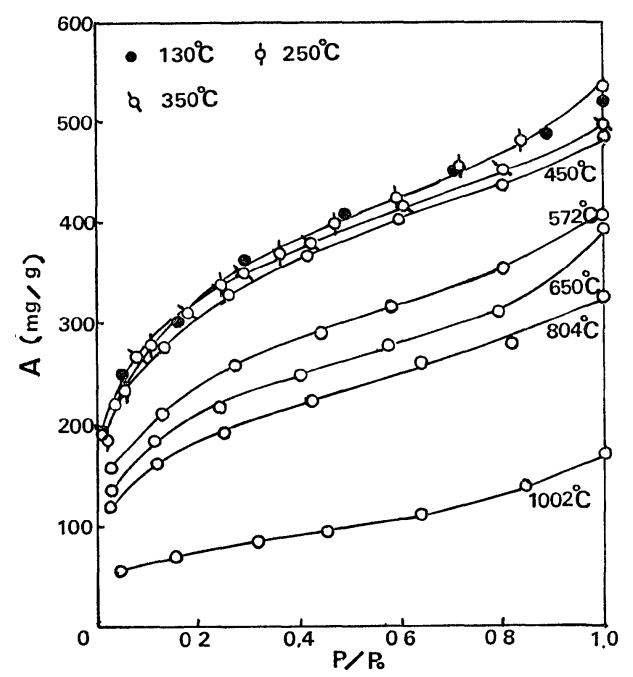

Fig. 2. Adsorption isotherms of argon on original silica gel, SK 6 calcinated at several temperatures.
る.したがってこれら等温線の相違は単分子吸着量の 減少に起因するものであり，これらのシリカゲルでは 毛管分布には変化はないことを示している. しかし $10022^{\circ} \mathrm{C}$ 処理 シリカゲルでは全比圧範囲にわたり吸着 量は減少する. この場合には単分子吸着量も著しく減 少し, 飽和吸着量から単分子吸着量を除いた全毛管吸 着量の著しい減少を示し，明らかに焼きしまり，すな わち焼結による毛管の減少を示している.これらの結 果から少くとも $450^{\circ} \mathrm{C}$ 以下の温度での加熱は基体であ るシリカゲルの毛管分布には変化を与えないと考觉ら れる.

$3 \cdot \mathbf{1} \cdot 2$ 表面積 $\quad 130 \sim 450^{\circ} \mathrm{C} て ゙$ 加熱したシリカゲ ルの吸着等温線を BET 式に適応して求められる表面 積は Fig. 3 ○印に示されるように $570 \mathrm{~m}^{2} / \mathrm{g}$ 前後でほ ぼ一定であるが，これより高温で加熱したものでは表 面積は減少している. とくに $1002^{\circ} \mathrm{C}$ 加熱のものでは $140 \mathrm{~m}^{2} / \mathrm{g}$ と著しい減少を示している。これは固結ま たは焼結などにより, 吸着分子径毛管（細げき）の消

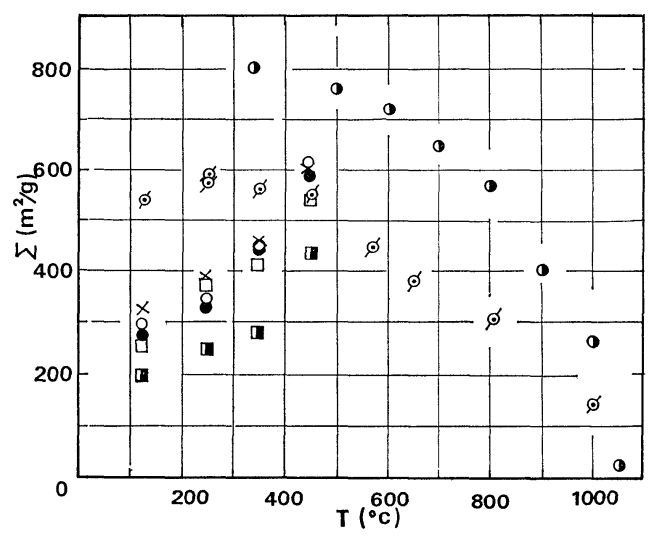

Fig. 3. Surface area of original and treated silica gels calcinated at several temperatures ( $\sigma$; SK6, ( data from ref., $\times$; CyPent SK41, $\bigcirc$; CyHex SK41, $\quad$; CyHept SK41, $\square$; CyHex MSK41, [U ; CyHex ESK41).

失，粒径の増加を示していると考えられる.このよう な傾向は同図に併示したの印のように，触媒の担体と して用いられたシリカゲルについての $\mathrm{N}_{2}$ 吸着から求 められた表面積からも認められた。 これらの結果も 450 C 以下の温度での加熱ではシリカゲルは焼結また は固結による単位粒径の増加はほとんどないと考光ら れる。

\section{$3 \cdot 2$ 表面処理程度の判定}

シリカゲルの表面処理条件, 表面積および元素分析 の炭素含量から，付着基は処理に用いたアルコールの アルコキシ基から成るとして求められる付着基数を Table I に示した. 表に示されるよらに付着基数は 2 $\sim 4 \times 10^{14} \mathrm{~cm}^{-2}$ の值であり，これらは従来報告された 
付着基数とほぼ同程度である. また処理シリカゲルの 赤外線吸収スペクトルはそれぞれ $\mathrm{CH}_{2}$ 基の伸縮振動 に帰属する特性吸収を示している．またこれらの表面 処理シリカゲルはいずれも水に投入すると油のよらに 水に浮いてなじまず, 粉体は媒水性表面を持つと認め られた.これらの結果から, シリカゲルは単脂環アル コールで充分表面処理されていると認めることができ た.

\section{$3 \cdot 3$ 表面処理シリカゲルの熱分解}

これら表面処理されたシリカゲルを先に述べたよう に $\mathrm{He}$ 気流中で加熱分解して, その付着基の熱的な挙
動を調べてみた. その結果を Fig. 4 に示した. 図示

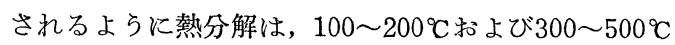
で起きることが認められる. 前者は物理吸着水あるい は吸着された未反応アルュールの脱離によるものと認 められる. 水の脱離は前者の温度領域より高温ででも 起るが，これは未反応シラノールの縮合脱水によるも のと考光られる. 付着基の熱分解は Fig. 4 (1), (2), (3)に示されるように CyPenSK41, CyHexSK41 およ び CyHeptSK41 では 300〜 $400{ }^{\circ} \mathrm{C}$ の範囲で起るが, CyHexMSK41 および CyHexESK41 ではこれより 高い 400 $500^{\circ} \mathrm{C}$ で起っている. これらの結果から

Table I. The conditions of surface-treatment, the surface area and number of surface group.

\begin{tabular}{|c|c|c|c|c|c|c|c|c|c|c|c|}
\hline Sample & Alcohol & $\begin{array}{l}\mathrm{S}_{2} \mathrm{O}_{2} \\
(\%)\end{array}$ & $\begin{array}{c}\text { Alcohol } \\
\text { (m1) }\end{array}$ & $\begin{array}{c}\text { Hexane } \\
(\mathrm{m} 1)\end{array}$ & $\begin{array}{c}P \\
(\mathrm{~kg} / \\
\left.\mathrm{cm}^{2}\right)\end{array}$ & $\begin{array}{c}T \\
\left({ }^{\circ} \mathrm{C}\right)\end{array}$ & $\begin{array}{c}C \\
(\%)\end{array}$ & $\begin{array}{c}\sum \\
\left(\mathrm{m}^{2} / \mathrm{g}\right)\end{array}$ & $\left|\begin{array}{c}N_{R} \times 10^{-21} \\
\left(\mathrm{~g}^{-1}\right)\end{array}\right|$ & $\left|\begin{array}{c}N_{R} \times 10^{-14} \\
\left(\mathrm{~cm}^{-2}\right)\end{array}\right|$ & $\begin{array}{l}N_{R^{\prime}} \\
\underset{\times 10^{-21}}{\left(\mathrm{~g}^{-1}\right)}\end{array}$ \\
\hline SK4 & & & & & & & & 572 & & & \\
\hline CyPenSK41 & $\mathrm{C}_{5} \mathrm{H}_{9} \mathrm{OH}$ & 2 & 10 & 60 & 30 & 241 & 7.71 & 327 & 0.77 & 237 & 1.00 \\
\hline 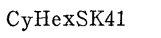 & $\mathrm{C}_{6} \mathrm{H}_{11} \mathrm{OH}$ & 4 & 10 & 60 & 30 & 242 & 1064 & 289 & 089 & 3.08 & 1.05 \\
\hline CyHeptSK41 & $\mathrm{C}_{7} \mathrm{H}_{13} \mathrm{OH}$ & 4 & 10 & 60 & 28 & 244 & 10.12 & 273 & 0.73 & 2.66 & 097 \\
\hline CyHexMSK41 & $\mathrm{C}_{6} \mathrm{H}_{11} \mathrm{CH}_{2} \mathrm{OH}$ & 4 & 5 & 65 & 30 & 240 & 885 & 252 & 0.63 & 252 & 0.47 \\
\hline CyHexESK41 & $\mathrm{C}_{6} \mathrm{H}_{11} \mathrm{CH}_{2} \mathrm{CH}_{2} \mathrm{OH}$ & 4 & 10 & 60 & 30 & 242 & 10.77 & 190 & 068 & 356 & 0.46 \\
\hline
\end{tabular}
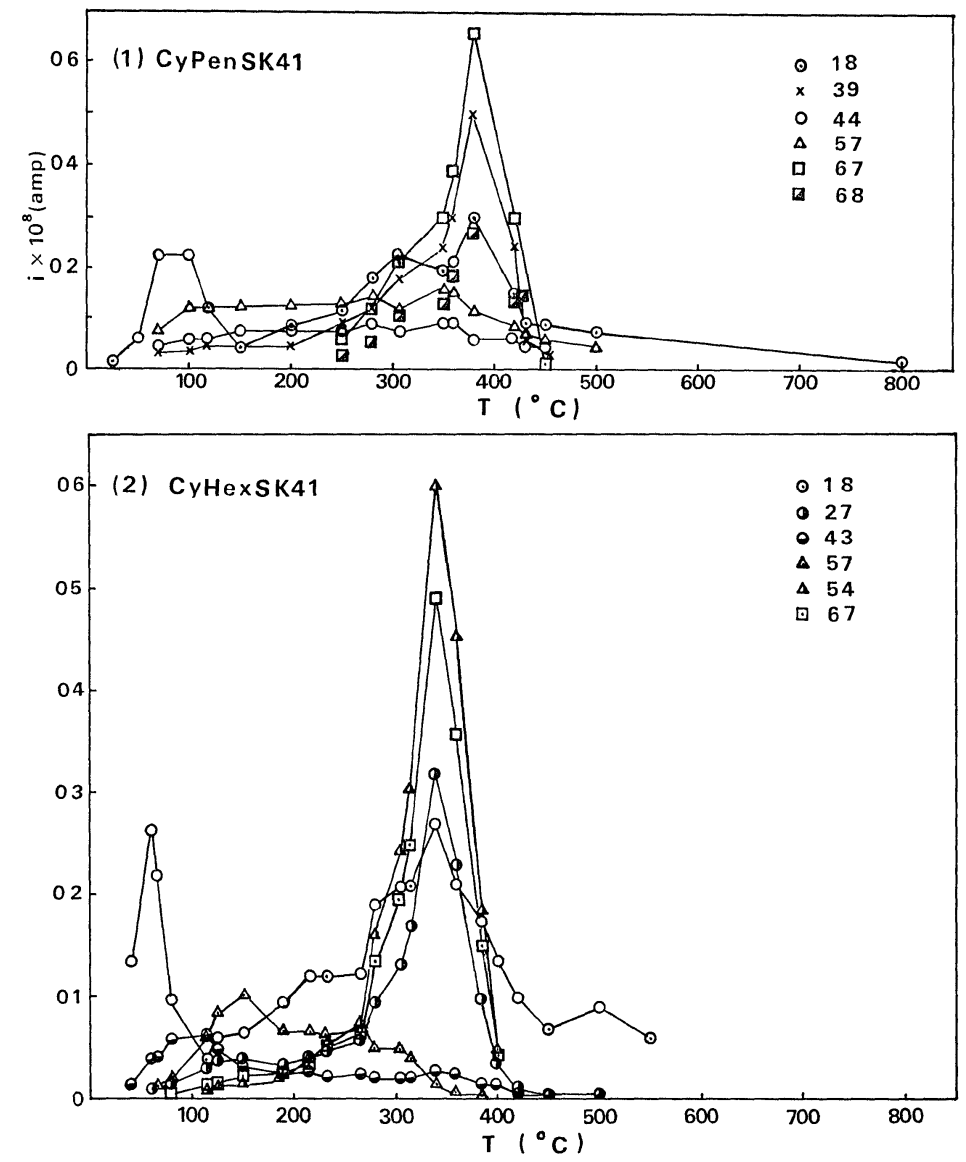

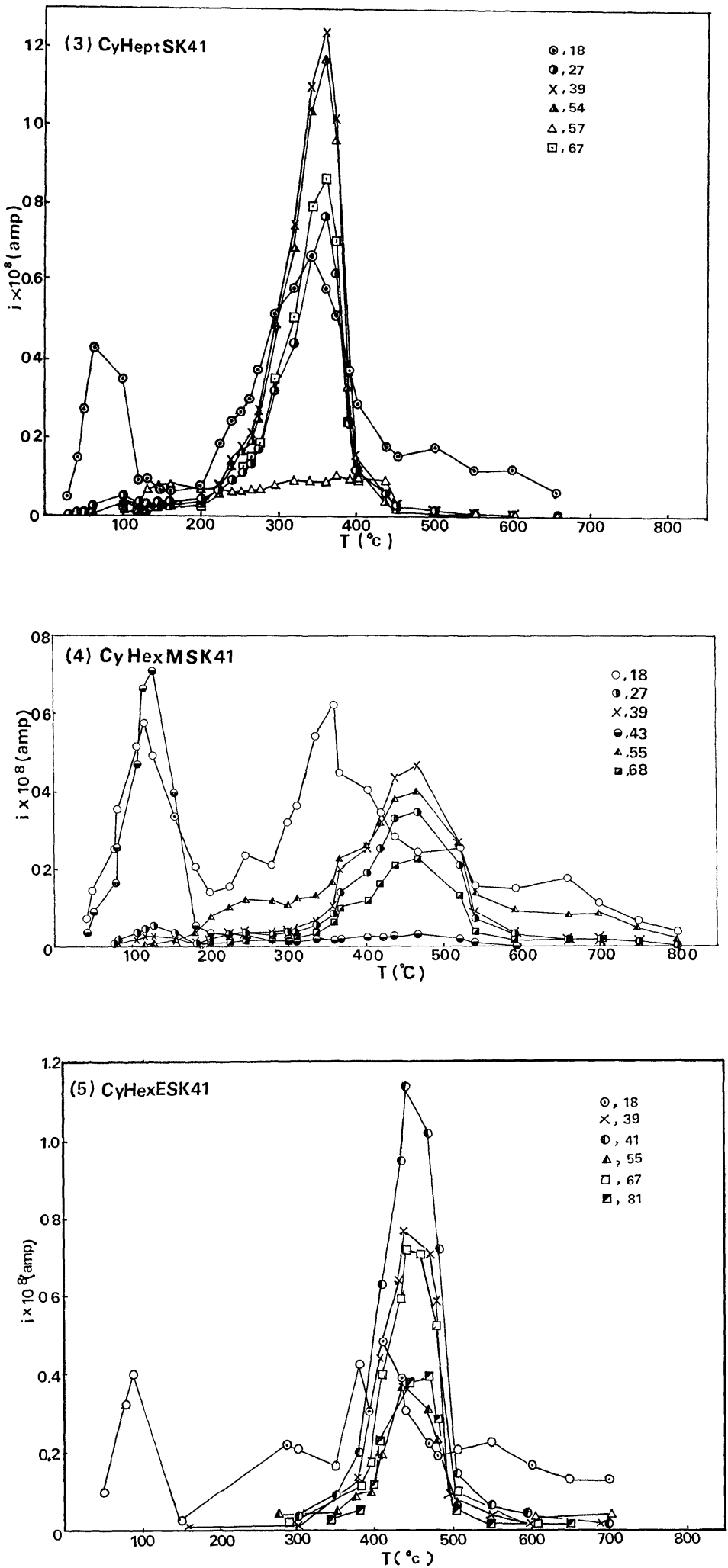

Fig. 4. Pyrolysis curves of silica gels treated with alcohols (1) CypenSK41, (2) CyHexSK41, (3) CyHeptSK41, (4) CyHexMSK41, (5) CyHexESK41. 
CyPenSK41〜CyHeptSK41 は $450^{\circ} \mathrm{C} て ゙$ 熱分解すれば 付着基はほぼ完全に除去されると考兄られる。こら のことは水または混合物分散媒への分散し好性が親水
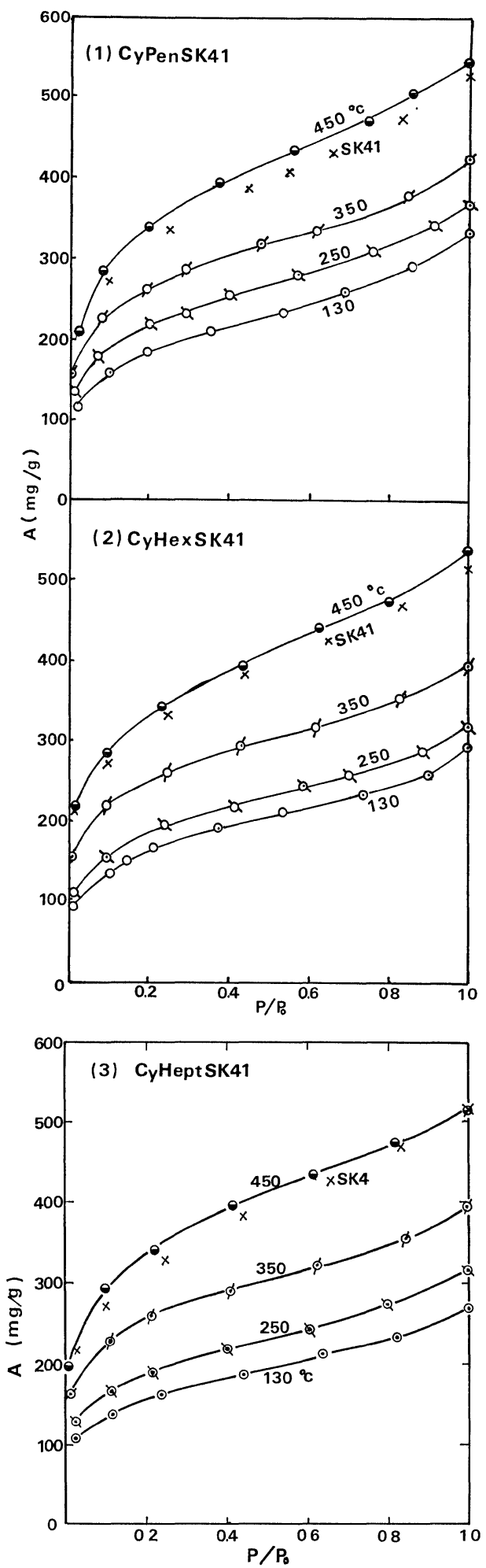

性であることからも確められた。他方, CyHexMSK41 あるいは CyHexESK41 では付着基を完全に除去する のには $500{ }^{\circ} \mathrm{C}$ 以上の温度で加熱を必要とするのであろ う.これらの傾向は $450^{\circ} \mathrm{C}$ 加熱処理による処理シリカ ゲルの重量減少からも CyHexMSK41 および CyHexE SK41 では付着基の残っていることが認められた.

$3 \cdot 4$ 表面処理処理シリカゲルの吸着等温線

$3 \cdot 4 \cdot 1$ 表面積 Table I に示されるように処理 シリカゲルの表面積は未㚭理シリカゲルの表面積より 小さい.この減少は分子断面積の増加につれて大きく なる傾向を示す．表面処理による表面積の減少は，末 処理シリカゲルには付着基でおおわれるとアルゴン等 の吸着分子の入り得ない分子径大の狭口径空孔が多数 あり，これらが付着基でおおわれることによるとして
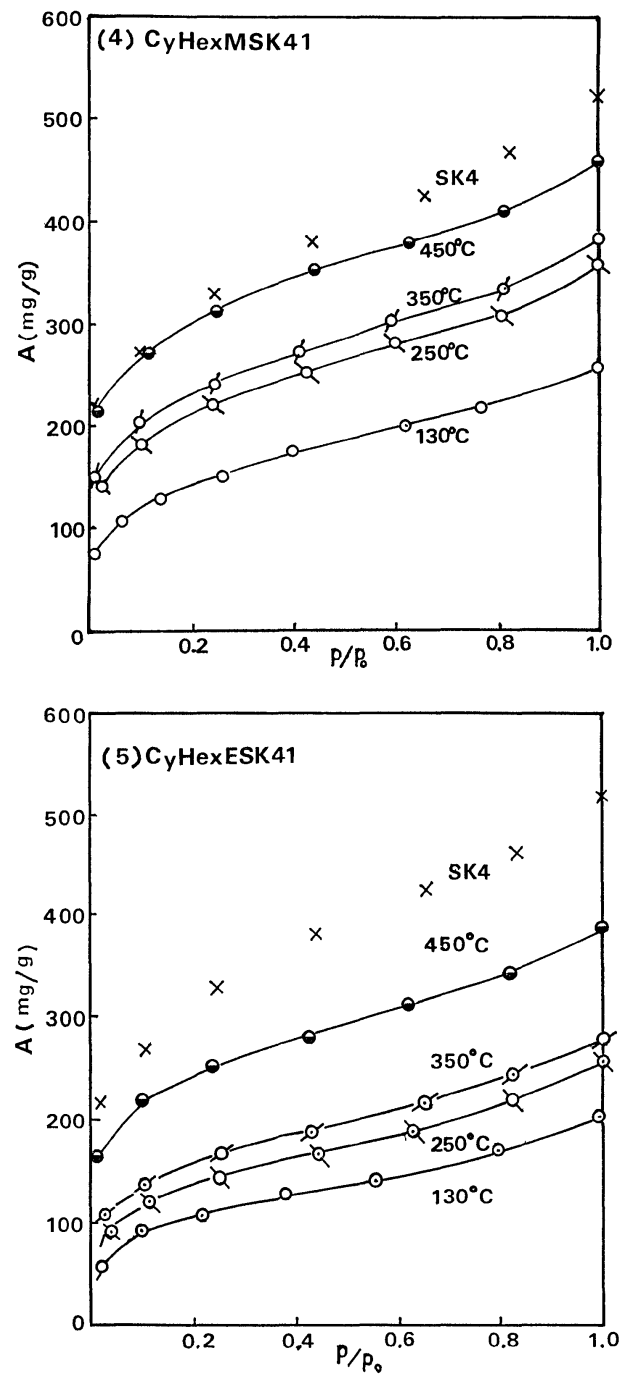

Fig. 5. Adsorption isotherms of treated silica gels after thermal treatment at 130,250 , 350 and $450^{\circ} \mathrm{C}$. 
説明された。 したがってこれらの傾向もこの観点から すれば合理的に説明可能である．これらの付着基を熱 分解で除去したシリカゲルの表面積はFig. 3 に併示さ れるように熱分解温度増加に伴い（付着基数の減少に 伴い）増加し，付着基の完全に除去されるとみられる $450^{\circ} \mathrm{C}$ 処理シリカゲル SK4 のそれ飞等しく, 泳ぼもと のシリカゲル SK4 のそれにもどることを示す.した がってこれらアルコールの表面処理であるシリカゲル の表面性状（表面積など）には変化のないことが認め られた。

$3 \cdot 4 \cdot 2$ 吸着等温線 Fig. 5 に示されるように, いずれのアルコールで処理したシリカゲルでも, 吸着 等温線は未処理シリカゲルのそれに比較して著しく小 さい，毛管凝縮の始まるとみられる比圧 0.15 以上では， 単分子吸着量を除いた吸着量は未処理シリカゲルの同 様にして表した吸着量にほぼ等しい。これら処理シリ カゲルを250, 350`で加熱した試料の場合も同じ傾向 を示す。このようにして表した吸着量はとれぞれの比 圧に相当する毛管半径までの毛管容に関係する量であ るから、これらがほぼ処理シリカゲルのそれに等しい ことは，吸着分子径より大きな孔径をるつ毛管分布は 表面処理によって変化しないことを示している.した がって表面処理シリカゲルで示される吸着量の減少は, 単分子吸着量の減少によるものであり, これは吸着分 子径に相当する毛管またはそれ以下の微少径毛管が, 表面処理で付加された付着基によって隠されるためで あると考兑られる， $4500^{\circ}$ で加熱した CyPenSK41, CyHexSK41 おょび CyHeptSK41 では Fig. 5 (1) (3)に示されるように未処理シリカゲルのとれにもどる ことを示している.しかし450゚で処理した CyHexM SK41 はいずれも未処理シリカゲルのそれより全比圧 範囲にわたり吸着量は減少して和り，その程度は側鎖
の長くなるほど大となる．Fig. 5 (4)に示されるように CyHexMSK41 では単分子吸着量は未処理のそれに ほぼ同じであるのに対し，高比圧部になるとその相違 は大となる。これは単分子吸着量を決める単位粒子の 径子粒には相違はないが，これらが二次的に集合して 形成される毛管分布に変化が生じたためであると考兄 られる. 熱分解曲線 Fig. 4 (4) と示されるようにこの 場合には300〜 550 $\mathrm{C}$ の範囲で著しい $\mathrm{H}_{2} \mathrm{O}$ の発生が認 められる. これが単位粒子の二次的集合状態に变化を 与えたるのと推定される.つぎに，CyHexESK41 で は単分子吸着量は未処理シリカゲルのそれより小さい が (表面積が小さい)，これはこの化合物の熱分解の 温度が高いことから，付着基は完全に除去されていな いためと考光られる.これより高比压部では, 単分子 吸着量を除いた吸着量は未処理シリカゲルのそれにほ ぼ一致するのであるから毛管分布には変化がないと考 光て差し支党ない。

以上より, 表面処理されたシリカゲルの表面積, 四 着等温線は未处理のそれとは異にして和り, しかも加 熱処理によりな和変化する. しかしこれらは $450^{\circ} \mathrm{C}$ 以 下ではシリカゲル基体の性質（毛管分布）には影響を 及ぼしていないと諗められた。

（昭和55年11月27日 第18回粉体江関する討論会にて講寅）

\section{参 考 文 献}

1) Marvine, F., and L. Johonson, J. Phys. Chem., 57, 865 (1954).

2）宇津木 弘, 表面, 11, 591，653 (1971).

3）宇津木 弘, 西村成興, 日化, 92, 759 (1971).

4) 宇津木 弘, 西村成興, 材料, 21, 534 (1972).

5）宇津木 弘, 西村成興, 島崎光雄, 日化, 2007 (1972).

6) 宇津木 弘, 西村成興, 材料, 22, 680 (1973).

7) 宇津木 弘, 西村成興, 色材, 48, 2 (1975). 